\title{
Developing a Steady-state Kinetic Model for Industrial Scale Semi-Regenerative Catalytic Naphtha Reforming Process
}

DOI: $10.15255 /$ KUI.2013.009

KUI-9/2014

Received April 11, 2013

Accepted June 4, 2013

\author{
R. Seif Mohaddecy and S. Sadighi \\ Catalysis and Nanotechnology Research Division, Catalytic Reaction Engineering Department, Research \\ Institute of Petroleum Industry, West Blvd. of Azadi Sports Complex, Tehran, Iran
}

\begin{abstract}
Due to the demand for high octane gasoline as a transportation fuel, the catalytic naphtha reformer has become one of the most important processes in petroleum refineries. In this research, the steady-state modelling of a catalytic fixed-bed naphtha reforming process to predict the momentous output variables was studied. These variables were octane number, yield, hydrogen purity, and temperature of all reforming reactors. To do such a task, an industrial scale semi-regenerative catalytic naphtha reforming unit was studied and modelled. In addition, to evaluate the developed model, the predicted variables i.e. outlet temperatures of reactors, research octane number, yield of gasoline and hydrogen purity were compared against actual data. The results showed that there is a close mapping between the actual and predicted variables, and the mean relative absolute deviation of the mentioned process variables were $0.38 \%, 0.52 \%, 0.54 \%, 0.32 \%, 4.8 \%$ and $3.2 \%$, respectively.
\end{abstract}

Key words: Catalytic naphtha reforming, modelling, simulation, kinetics

\section{Introduction}

The catalytic reforming of heavy naphtha (heavy straight run gasoline or HSRG) is a favourite process in petroleum refineries due to producing high-octane gasoline. ${ }^{1}$ The semi-regenerative naphtha reformer is the oldest type where reactions are carried out in three or four adiabatic fixed-bed reactors in series, each of which is equipped with a pre-heater. This plant usually operates at temperatures between $450{ }^{\circ} \mathrm{C}$ and $520{ }^{\circ} \mathrm{C}$, total pressure between 25 and $35 \mathrm{~atm}$, and hydrogen-to-hydrocarbon amount ratios between 3 and 7.1,2,3

Usually, the feed of the catalytic reforming process is HSRG, including four hydrocarbon groups i.e. paraffins, olefins, naphthenes and aromatics (PONA) with number of carbon atoms between 5 and 10 .

The main reforming reactions occurring through the catalytic beds are dehydrocyclization, hydrocracking, isomerization, dehydrogenation and cyclization. Some of these reactions are desired for increasing octane number of gasoline, whereas others are undesired because they decrease it. For paraffins, increment of octane number is the result of reactions increasing the number of branches, such as cyclization and aromatization. Therefore, normal paraffins conversion to isoparaffins, naphthenes, and aromatics can increase the octane number. ${ }^{3}$

The catalytic reforming process is often modelled based on: 1) the number of reactive species, and 2) the type of the used kinetic model. However, the presence of many com-

"Corresponding author: Reza Seif Mohaddecy, email: seifsr@ripi.ir, Tel. +98-21-48255051, Fax. +98-21-44739709, P.O. Box 14665-137 ponents as reactants or products causes numerous reactions. Therefore, the situation is extremely sophisticated for process modelling. To decrease these complications, reactants in the mixture are classified into limited groups called pseudo-components or lumps. The number of selected lumps in the mixture is a determinant factor for designing the reforming model. Arrhenius and Langmuir-Hinshelwood kinetics are widely used for catalytic reforming models.

In the field of catalytic naphtha process modelling, a simple and first model was suggested by Smith ${ }^{4}$ in which naphtha reforming was considered as a combination of only four reactions. Then, in 1997, Taskar suggested a model for the catalytic reforming reaction that consisted of 35 pseudo-components in the reaction network and 36 reactions. ${ }^{5}$ Following the use of Arrhenius kinetics, a well-known model was proposed by Padmavathi ${ }^{6}$ in 1997 in which 26 pseudo-components, such as alkyl cyclohexane $(\mathrm{ACH})$, alkyl cyclopentane (ACP), normal paraffins (NP), isoparaffins (IP), aromatics $(A)$, hydrogen $\left(\mathrm{H}_{2}\right)$ and light hydrocarbons $\left(\mathrm{C}_{1}\right.$ to $\mathrm{C}_{5}$ ) were used in the network. Ancheyta et al. ${ }^{7}$ developed a kinetic model for the naphtha catalytic reforming process. This model utilized a lumped mathematical model, presenting the reactions ranging from 1 to 11 carbon atoms for paraffins, and from 6 to 11 carbon atoms for naphthenes and aromatics. In 2003 Rahimpour et al. presented a kinetic model for industrial scale catalytic naphtha reformers, including deactivation of the catalyst. The impact of inlet temperature, operating pressure and catalyst mass distribution on the performance of the reactors was examined. The results indicated an increase in aromatic yield with increasing inlet temperature. However, manipulating the operating pressure had no appreciable effect on the gasoline yield. Additionally, this model estimated catalyst deactiva- 
tion where the corresponding parameters were estimated using the plant data. ${ }^{8}$ In 2006 Hou et al. presented a new 18-lump kinetic-based mathematical model for an industrial continuous catalytic reforming plant. In this model, reaction temperature and concentration profiles of all reactors, heater duties, catalyst deactivation, recycle gas composition and octane number for different feedstock or operating conditions could be predicted. ${ }^{9}$ In the next effort in 2009 Arani et al. developed a lumping procedure to obtain kinetic and thermodynamic parameters of catalytic naphtha reformer using a model consisting of 17 lumps ranging from $\mathrm{C}_{6}$ to $\mathrm{C}_{8}+$ hydrocarbon, and including 15 reaction pathways. ${ }^{10}$ In the same year Fatemi et al. developed a mathematical model for a commercial naphtha catalytic reformer which included three sequencing catalytic fixed-bed reactors at steady-state condition. They used a detailed kinetic scheme involving 26 pseudo-components connected by a network of 47 reactions. The output variables of the reformer, such as RON (research octane number) and yield of gasoline showed good agreement with actual data obtained from the under study reforming unit. ${ }^{11}$ Recently Ziaoon presented a detailed kinetic model including 24 components, 1 to 11 carbon atoms for paraffins, and 6 to 11 carbon atoms for naphthenes and aromatics, forming 71 reactions. ${ }^{12}$

In this paper, in order to model an industrial scale catalytic naphtha reforming process, a steady-state kinetic model including 9 pseudo-components and 4 reactions was developed. In comparison to the complex models proposed for this process, this model can also show low average absolute deviation against actual data.

\section{Process description}

A commercial fixed-bed catalytic naphtha reforming unit, called Platformer, licensed by Chevron research cooperation was chosen as a case study. The feed of the plant prior to entering the catalytic reformer should undergo hydrodesulphurization (HDS) reaction in the hydrotreatment unit. Then, the produced naphtha, called Platcharge, is introduced to the reforming process. The most commonly used types of catalytic reforming units have three or four reactors each having a fixed catalytic bed. ${ }^{3,4}$

As shown in Fig. 1, Platcharge is first preheated by the first furnace $(\mathrm{H}-1)$, and then it enters the first reactor $(\mathrm{R}-1)$ where the naphthenes are dehydrogenated to aromatics. The product stream from the first reactor then passes through the second reactor (R-2), and enters the third reactor (R-3). The overall reforming reactions are endothermic; therefore, a preheater $(\mathrm{H}-1, \mathrm{H}-2$, and $\mathrm{H}-3)$ should essentially be provided before each reforming reactor.

Next, the product stream from the third reactor enters the flash separator $(\mathrm{V}-1)$ wherein the produced hydrogen is separated, and recycled to the beginning of the process. This recycled stream is then mixed with the fresh naphtha feed (Platcharge). Finally, the liquid product leaving the separator is introduced to the gasoline stabilizer in which the LPG and light gases are separated from the gasoline. So, the vapour pressure of the gasoline can be set according to the market requirement.

The specifications of feed and catalyst distribution of the studied catalytic naphtha reforming plant are given in Tables 1 and 2. The normal operating conditions of the unit are presented in Table 3.

The design pressure of the studied catalytic reforming plant was 34 bar. However, depending on the feed specification and deactivation of the catalyst, the operating pressure of the plant could be varied between 27 and 32 bar. So, the effect of the pressure on reforming reactions was included in the model, which is discussed later.

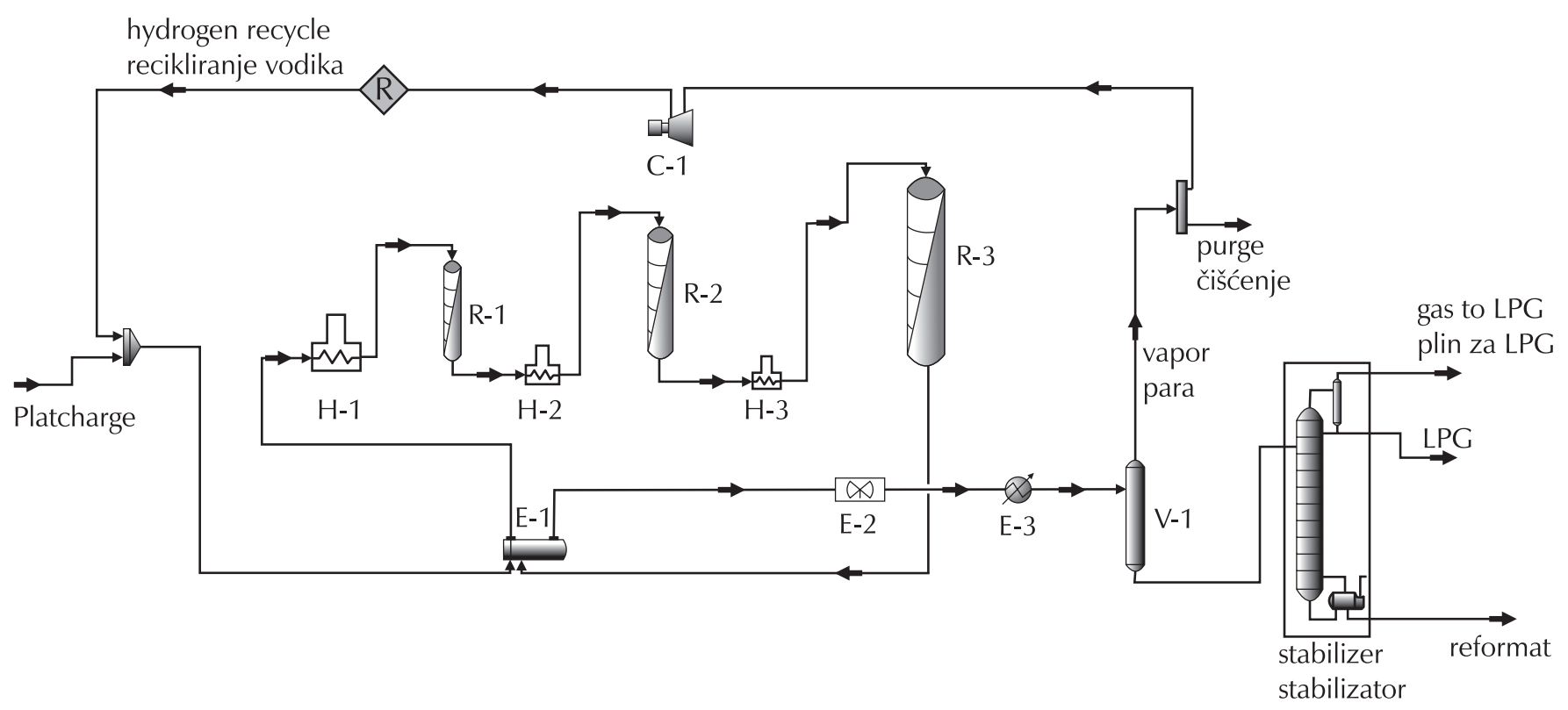

F i g . 1 - Catalytic reforming flowchart (semi-regenerative)

S I i k a 1 - Dijagram toka poluobnavljajućeg katalitičkog reformiranja 
T a b l e 1 - Specification of feed of catalytic naphtha reforming process

T a b I i c a 1 - Sirovina za katalitičko reformiranje benzina

\begin{tabular}{|c|c|}
\hline $\begin{array}{l}\text { Variable } \\
\text { Veličina }\end{array}$ & $\begin{array}{c}\text { Value } \\
\text { Vrijednost }\end{array}$ \\
\hline $\begin{array}{l}\text { density / } \mathrm{g} \mathrm{cm}^{-3} \\
\text { gustoća / } \mathrm{g} \mathrm{cm}^{-3}\end{array}$ & 0.745 \\
\hline \multicolumn{2}{|c|}{$\begin{array}{l}\text { distillation method (ASTM D86) } \\
\text { destilacija po normi ASTM D86 }\end{array}$} \\
\hline $\begin{array}{l}\text { volume fraction } \\
\text { obujamski udjel }\end{array}$ & $\begin{array}{c}\text { boiling point } /{ }^{\circ} \mathrm{C} \\
\text { vrelište } /{ }^{\circ} \mathrm{C}\end{array}$ \\
\hline IBP & 88 \\
\hline $10 \%$ & 99 \\
\hline $30 \%$ & 105 \\
\hline $50 \%$ & 113 \\
\hline $70 \%$ & 123 \\
\hline $90 \%$ & 137 \\
\hline FBP & 156 \\
\hline \multicolumn{2}{|c|}{$\begin{array}{l}\text { PONA analysis } \\
\text { analiza PONA }\end{array}$} \\
\hline $\begin{array}{l}\text { components } \\
\text { komponente }\end{array}$ & $\begin{array}{l}\text { volume fraction } \\
\text { obujamski udjel }\end{array}$ \\
\hline $\begin{array}{l}\text { paraffins } \\
\text { parafini }\end{array}$ & $55 \%$ \\
\hline $\begin{array}{l}\text { aromatics } \\
\text { aromati }\end{array}$ & $12 \%$ \\
\hline $\begin{array}{l}\text { naphthenes } \\
\text { nafteni }\end{array}$ & $33 \%$ \\
\hline
\end{tabular}

Ta ble 2 - Catalyst distribution in reforming reactors

T a bli c a 2 - Raspodjela katalizatora u reaktorima

\begin{tabular}{c|c|c|c}
\hline & $\begin{array}{c}1^{\text {st }} \text { reactor } \\
\text { 1. reaktor }\end{array}$ & $\begin{array}{c}2^{\text {nd }} \text { reactor } \\
\text { 2. reaktor }\end{array}$ & $\begin{array}{c}3^{\text {rd }} \text { reactor } \\
\text { 3. reaktor }\end{array}$ \\
\hline $\begin{array}{c}\text { catalyst mass } \\
\text { masa katalizatora }\end{array}$ & $8648 \mathrm{~kg}$ & $14223 \mathrm{~kg}$ & $22452 \mathrm{~kg}$ \\
$\begin{array}{c}\text { catalyst mass distribution } \\
\text { raspodjela katalizatora }\end{array}$ & $20 \%$ & $30 \%$ & $50 \%$ \\
\hline
\end{tabular}

T a b l e 3 - Operating conditions in the catalytic reforming of the target oil refinery

T a b I i c a 3 - Uvjeti katalitičkog reformiranja u rafineriji

\begin{tabular}{c|c}
\hline $\begin{array}{c}\text { Process variable } \\
\text { Procesna varijabla }\end{array}$ & $\begin{array}{c}\text { Value } \\
\text { Vrijednost }\end{array}$ \\
\hline $\begin{array}{c}\text { inlet temperature } /{ }^{\circ} \mathrm{C} \\
\text { ulazna temperatura } /{ }^{\circ} \mathrm{C}\end{array}$ & $490-515$ \\
$\begin{array}{c}\text { hydrogen/hydrocarbon amount ratio } \\
\text { množinski omjer vodika i ugljikovodika }\end{array}$ & $3-7$ \\
$\mathrm{LHSV} / \mathrm{h}^{-1}$ & $1-2$ \\
$\begin{array}{c}\text { volume yield } / \% \\
\text { obujamsko iskorištenje } / \%\end{array}$ & $70-85$ \\
\hline
\end{tabular}

\section{Development of kinetic model ${ }^{4}$}

In the present study, in order to simulate a catalytic reforming unit, the naphtha feed is classified into three general lumps i.e. aromatics, naphthenes and paraffins. Also considered were hydrogen, methane, propane, butane, and pentane. The reactions within this model are classified into four groups, as follows:

\section{Naphthenes to aromatics}

$$
\text { naphtenes } \rightleftharpoons \text { aromatics }+3 \mathrm{H}_{2}
$$

Rate constants concerning this reaction are as follows: ${ }^{4}$

$$
\begin{aligned}
K_{\text {eq } 1} & =\exp \left(46.15-\frac{46045}{T /{ }^{\circ} \mathrm{R}}\right) \\
k_{\mathrm{c} 1} & =\exp \left(23.21-\frac{34750}{T /{ }^{\circ} \mathrm{R}}\right)
\end{aligned}
$$

\section{Naphthenes to paraffins}

$$
\text { naphthenes }+\mathrm{H}_{2} \rightleftharpoons \text { paraffins }
$$

Rate constants concerning this reaction are as follows: ${ }^{4}$

$$
\begin{gathered}
K_{\text {eq2 }}=\exp \left(-7.12+\frac{8000}{T /{ }^{\circ} \mathrm{R}}\right) \\
k_{\mathrm{c} 2}=\exp \left(35.98-\frac{59600}{T /{ }^{\circ} \mathrm{R}}\right)
\end{gathered}
$$

\section{Hydrocracking of paraffins}

$$
\text { paraffins }+\left(\frac{N-1}{3}\right) \mathrm{H}_{2} \rightarrow \frac{N}{15} \sum_{i=1}^{5} \mathrm{C}_{i} \mathrm{H}_{2 i+2}
$$

The rate of paraffins cracking and rate constants concerning this reaction are as follows: ${ }^{4}$

$$
\begin{aligned}
& -r_{\text {P-cracking }}=k_{\mathrm{c} 3} \frac{p_{\mathrm{P}}}{p_{\mathrm{T}}} \\
& k_{\mathrm{c} 3}=\exp \left(42.97-\frac{62300}{T /{ }^{\circ} \mathrm{R}}\right)
\end{aligned}
$$

\section{Hydrocracking of naphthenes}

$$
\text { naphthenes }+\frac{N}{3} \mathrm{H}_{2} \rightarrow \frac{N}{15} \sum_{i=1}^{5} \mathrm{C}_{i} \mathrm{H}_{2 i+2}
$$

The rate of naphthenes cracking and rate constants concerning this reaction are as follows: ${ }^{4}$

$$
\begin{aligned}
& -r_{\mathrm{N}-\text { cracking }}=k_{\mathrm{c} 4} \frac{p_{\mathrm{N}}}{p_{\mathrm{T}}} \\
& k_{c 4}=\exp \left(42.97-\frac{62300}{T /{ }^{\circ} \mathrm{R}}\right)
\end{aligned}
$$

Using the presented rate equations, the mass and energy conservations can be written as follows:

$$
\frac{\mathrm{d} n_{\mathrm{A}}}{\mathrm{d} V_{\mathrm{R}}}=\frac{k_{\mathrm{c} 1}}{K_{\text {eq1 } 1}} p_{\mathrm{N}}\left(K_{\text {eq1 } 1}-\frac{p_{\mathrm{A}} p_{\mathrm{H}_{2}}^{3}}{p_{\mathrm{N}}}\right)
$$

$$
\begin{aligned}
\frac{\mathrm{d} n_{\mathrm{N}}}{\mathrm{d} V_{\mathrm{R}}} & =\frac{k_{\mathrm{c} 1}}{K_{\text {eq1 }}} p_{\mathrm{N}}\left(K_{\text {eq1 } 1}-\frac{p_{\mathrm{A}} p_{\mathrm{H}_{2}}^{3}}{p_{\mathrm{N}}}\right)- \\
& -\frac{k_{\mathrm{c} 2}}{K_{\text {eq }}} p_{\mathrm{N}}\left(K_{\text {eq2 } 2}-\frac{p_{\mathrm{A}}}{p_{\mathrm{N}} p_{\mathrm{H}_{2}}}\right)-k_{\mathrm{c} 4} \frac{p_{\mathrm{N}}}{p_{\mathrm{T}}} \\
\frac{\mathrm{d} n_{\mathrm{P}}}{\mathrm{d} V_{\mathrm{R}}} & =\frac{k_{\mathrm{c} 2}}{K_{\text {eq2 }}} p_{\mathrm{N}}\left(K_{\text {eq2 }}-\frac{p_{\mathrm{A}}}{p_{\mathrm{N}} p_{\mathrm{H}_{2}}}\right)-k_{\mathrm{c} 3} \frac{p_{\mathrm{P}}}{p_{\mathrm{T}}}
\end{aligned}
$$




$$
\begin{aligned}
\frac{\mathrm{d} T}{\mathrm{~d} V_{\mathrm{R}}}= & -\frac{k_{\mathrm{c} 1}}{K_{\mathrm{eq} 1}} p_{\mathrm{N}}\left(K_{\mathrm{eq} 1}-\frac{p_{\mathrm{A}} p_{\mathrm{H}_{2}}^{3}}{p_{\mathrm{N}}}\right) \frac{\Delta H_{1}}{n_{\mathrm{T}} C_{\mathrm{P}}}- \\
& -\frac{k_{c 2}}{K_{\text {eq } 2}} p_{\mathrm{N}}\left(K_{\mathrm{eq} 2}-\frac{p_{\mathrm{A}}}{p_{\mathrm{N}} p_{\mathrm{H}_{2}}}\right) \frac{\Delta H_{2}}{n_{\mathrm{T}} C_{\mathrm{P}}}- \\
& -\frac{k_{c 3}}{p_{\mathrm{T}}} p_{\mathrm{N}} \frac{\Delta H_{3}}{n_{\mathrm{T}} c_{\mathrm{P}}} \frac{N}{3}-k_{c 4} \frac{p_{\mathrm{P}}}{p_{\mathrm{T}}} \frac{\Delta H_{4}}{n_{\mathrm{T}} C_{\mathrm{P}}} \frac{N-3}{3},
\end{aligned}
$$

where $n$ is the number of each presumed carbon of pseudo-components ${ }^{4}$ which is between 7 and 6 for the feed in the model.

\section{Results and discussions}

After developing the kinetic model using data obtained from a pilot-scale catalytic naphtha reforming unit, it should be scaled up to the industrial scale. An optimization subroutine was used to determine the coefficients until reaching a suitable consistency between the industrial data and the model results. In this subroutine, the Levenburg-Marquardt optimization algorithm was used, and the following target function was optimized:

$$
f=\sum_{i=1}^{n}\left(0.5\left(c_{i \exp }-C_{i \text { model }}\right)^{2}+0.5\left(T_{i \exp }-T_{i \text { model }}\right)^{2}\right)
$$

The magnitudes of constants are presented in Table 4 for the studied reforming plant.

T a b I e 4 - Reaction constants calculated using optimized approach

T a b l i c a 4 - Konstante izračunate optimiziranim pristupom

\begin{tabular}{c|l|c|c}
\hline $\begin{array}{l}\text { Reaction } \\
\text { number } \\
\text { Broj reakcije }\end{array}$ & $\begin{array}{l}\text { Reaction name } \\
\text { Naziv reakcije }\end{array}$ & $k_{0}$ & $\frac{E_{\mathrm{a}}}{R} /{ }^{\circ} \mathrm{R}$ \\
\hline 1 & $\begin{array}{l}\text { aromatic production } \\
\text { nastajanje aromata }\end{array}$ & 18.59 & 34807 \\
2 & $\begin{array}{l}\text { paraffins production } \\
\text { nastajanje parafina }\end{array}$ & 26.74 & 58591 \\
3 & $\begin{array}{l}\text { paraffins hydrocracking } \\
\text { hidrokrekiranje parafina }\end{array}$ & 42.97 & 62857 \\
4 & $\begin{array}{l}\text { naphthenes hydrocracking } \\
\text { hidrokrekiranje naftena }\end{array}$ & & \\
& & & \\
\hline
\end{tabular}

Now, in order to evaluate the accuracy of the model, the simulated data were compared with the actual (industrial) data. Figs. 2 to 4 show comparisons between the outlet reactor temperatures obtained by the model against the actual values. The results showed that AAD of the predicted reactor temperatures were $0.38 \%, 0.52 \%$ and $0.54 \%$, respectively. From Figs. 2 to 4, close mappings between the measured and simulated outlet temperatures of reactors can be observed.

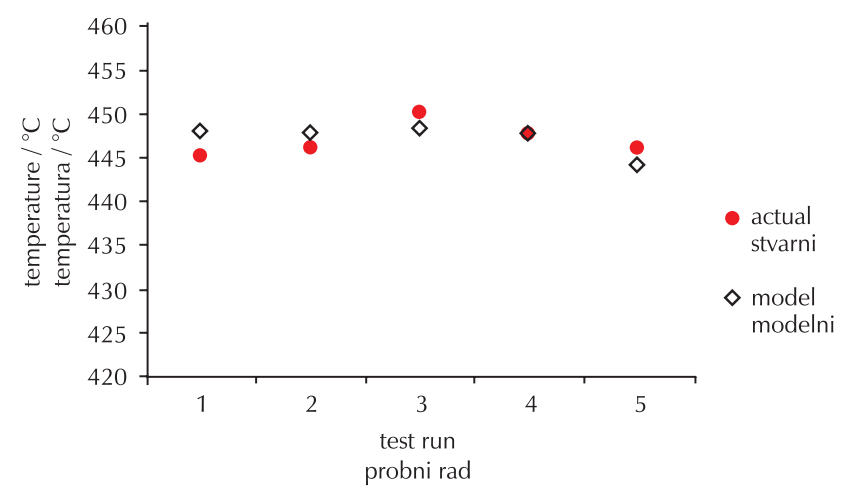

Fig. 2 - Simulated outlet temperature of $1^{\text {st }}$ reactor against actual values

Slika 2 - Simulirana ulazna temperatura 1. reaktora u usporedbi sa stvarnim vrijednostima

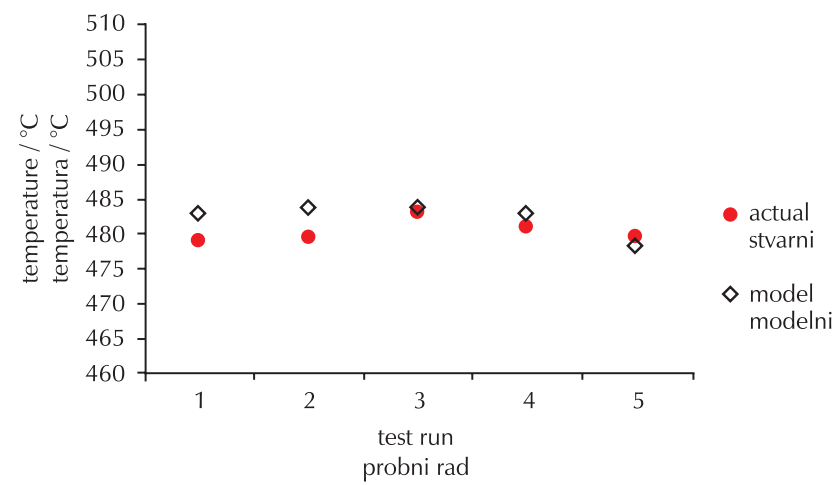

F i g . 3 - Simulated outlet temperature of $2^{\text {nd }}$ reactor against actual values

Slika 3 - Simulirana ulazna temperatura 2. reaktora u usporedbi sa stvarnim vrijednostima

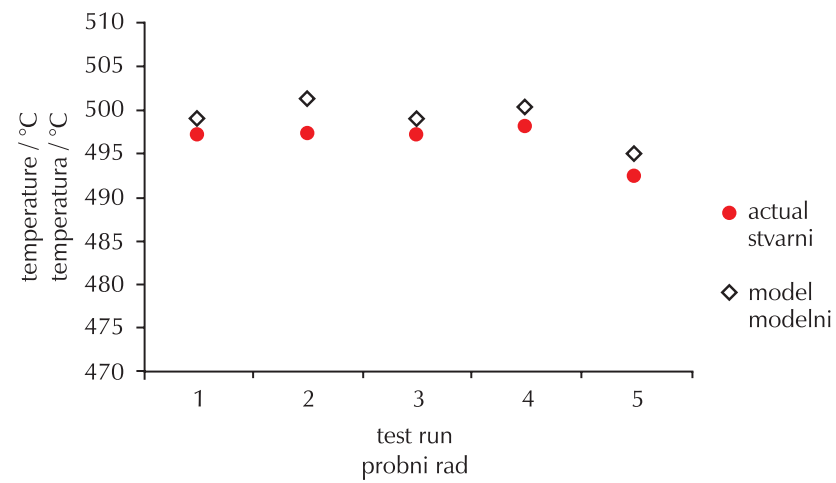

F i g . 4 - Simulated outlet temperature of $3^{\text {rd }}$ reactor against actual values

Slika 4 - Simulirana ulazna temperatura 3. reaktora u usporedbi sa stvarnim vrijednostima

Other significant operating parameters in catalytic reforming are product volume yield and RON. Comparisons of the predicted product volume yield and RON with the actual data are shown in Figs. 5 and 6. From these figures, close mappings between the measured and simulated product volume yield and RON can be observed. Moreover, it is found that the presented model can simulate the RON and volume yield of gasoline with AAD of $0.32 \%$ and $4.8 \%$, respectively. These results confirm that the presented approach can reliably be applied by refineries to monitor the operation of the catalytic reforming plant. 


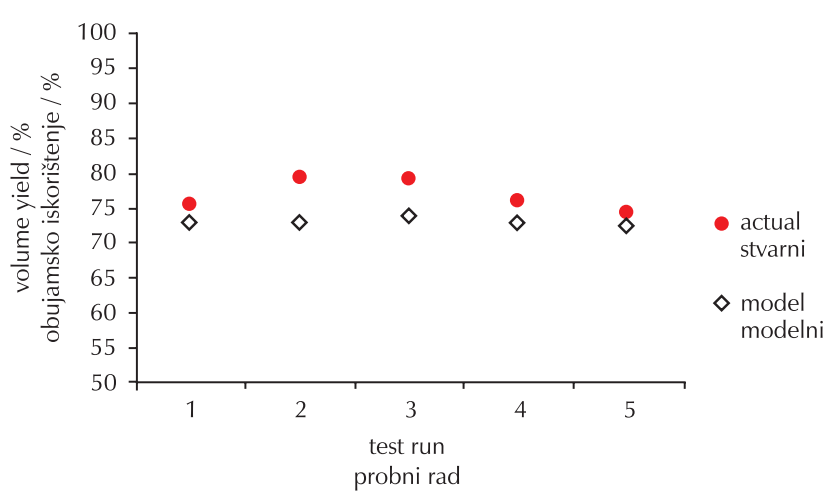

F i g . 5 - Simulated volume yield of gasoline against actual values Slik a 5 - Simulirano obujamsko iskorištenje benzina u usporedbi sa stvarnim vrijednostima

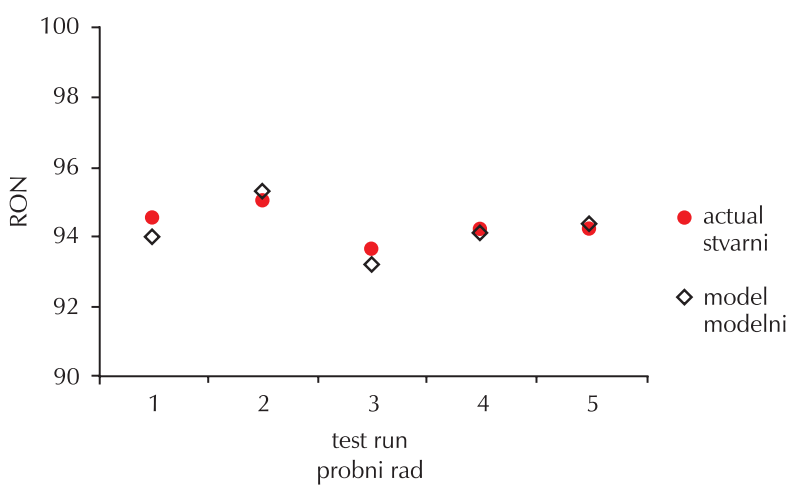

F i g . 6 - Simulated RON of product against actual values

Slika 6 - Simulirani RON produkta u usporedbi sa stvarnim vrijednostima

The other significant parameter in the catalytic reforming plant is the hydrogen purity of the recycle stream. Fig. 7 presents the comparison between the simulated hydrogen purity and the actual data. These results show that the kinetic model can predict the purity of the produced hydrogen with AAD of $3.19 \%$. It is concluded that the presented kinetic model is also good for predicting the purity of hydrogen produced in the catalytic naphtha reforming unit.

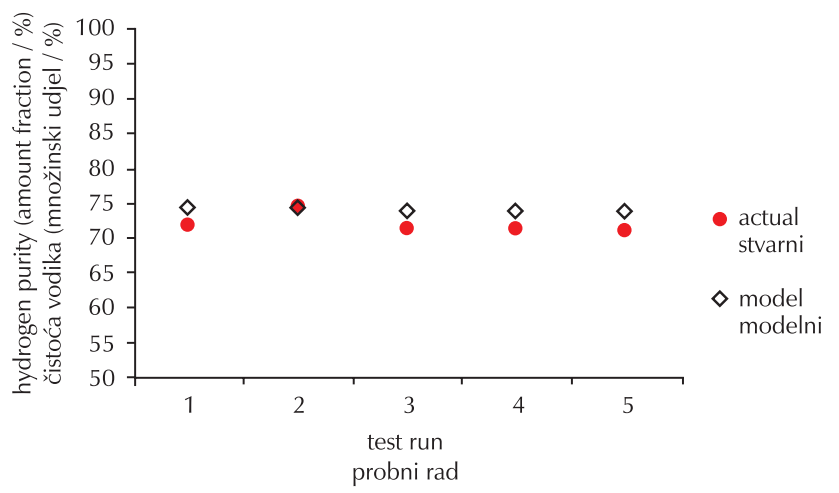

Fig. 7 - Simulated hydrogen purity (expressed as volume fraction) against actual values

Slika 7 - Simulirana čistoća vodika (izražena kao množinski udjel) u usporedbi sa stvarnim vrijednostima

\section{Conclusions}

The catalytic reforming of heavy naphtha (heavy straight run gasoline or HSRG) is a favourite process in petroleum refineries for producing high-octane gasoline. In this research, significant process variables of a commercial naphtha catalytic reforming plant were modelled using a heterogeneous kinetic model. These variables included the outlet temperatures of the first, second and third reactors, RON of gasoline, product volume yield and hydrogen purity. To evaluate the proposed model, the results were compared against data obtained from a commercial catalytic naphtha reformer. It was found that the mean relative absolute deviation (AAD) of the mentioned parameters were $0.38 \%, 0.52 \%, 0.54 \%$, $0.32 \%, 4.8 \%$ and $3.2 \%$, respectively. Therefore, a close mapping was confirmed between the simulated variables and data obtained from an industrial-scale reforming plant. These results show that the presented kinetic model can reliably be utilized to monitor the operation of the catalytic reforming plant.

\section{List of symbols and abbreviations Popis simbola i kratica}

C $\quad$ - amount concentration, $\mathrm{mol} \mathrm{m}^{-3}$

- množinska koncentracija, mol m ${ }^{-3}$

$c_{\mathrm{p}} \quad-$ heat capacity at constant pressure, $\mathrm{J} \mathrm{K}^{-1} \mathrm{~mol}^{-1}$

- toplinski kapacitet pri stalnom tlaku, J $\mathrm{K}^{-1} \mathrm{~mol}^{-1}$

$E_{\mathrm{a}} \quad$ - activation energy, $\mathrm{J} \mathrm{mol}^{-1}$

- aktivacijska energija, J $\mathrm{mol}^{-1}$

$\Delta H \quad$ - enthalpy, $\mathrm{J} \mathrm{mol}^{-1}$

- entalpija, J mol ${ }^{-1}$

$K_{\text {eq }} \quad-$ equilibrium constant

- ravnotežna konstanta

k - - rate reaction constant

- konstanta brzine reakcije

$k_{0} \quad$ - pre-exponential factor

- predeksponencijalni faktor

N $\quad$ - number of atoms

- broj atoma

$n_{\mathrm{A}} \quad-$ amount of aromatics, mol

- množina aromata, mol

$n_{N} \quad-$ amount of naphthenes, mol

- množina naftena, mol

$n_{\mathrm{P}} \quad-$ amount of paraffins, mol

- množina parafina, mol

$n_{\mathrm{T}} \quad-$ total amount of substance, $\mathrm{mol}$

- ukupna množina tvari, mol

$p_{\mathrm{A}} \quad-$ partial pressure of aromatics, atm

- parcijalni tlak aromata, atm

$p_{\mathrm{N}} \quad-$ partial pressure of naphthenes, atm

- parcijalni tlak naftena, atm

$p_{\mathrm{P}} \quad-$ partial pressure of paraffins, atm

- parcijalni tlak parafina, atm

$p_{\mathrm{T}} \quad-$ total pressure, atm

- ukupni tlak, atm

$R \quad$ - universal gas constant, $R=8.314 \mathrm{~J} \mathrm{~K} \mathrm{~mol}^{-1}$

$=4,619 \mathrm{~J}^{\circ} \mathrm{R} \mathrm{mol}^{-1+}$

- opća plinska konstanta, $R=8.314 \mathrm{~J} \mathrm{~K} \mathrm{~mol}^{-1}$

$=4,619 \mathrm{~J}^{\circ} \mathrm{R} \mathrm{mol}-1+$

$r_{\mathrm{N} \text {-crack- }}$ - naphthenes cracking rate

ing - brzina krekiranja naftena

$r_{\text {P-cracking }}-$ paraffins cracking rate

- brzina krekiranja parafina 


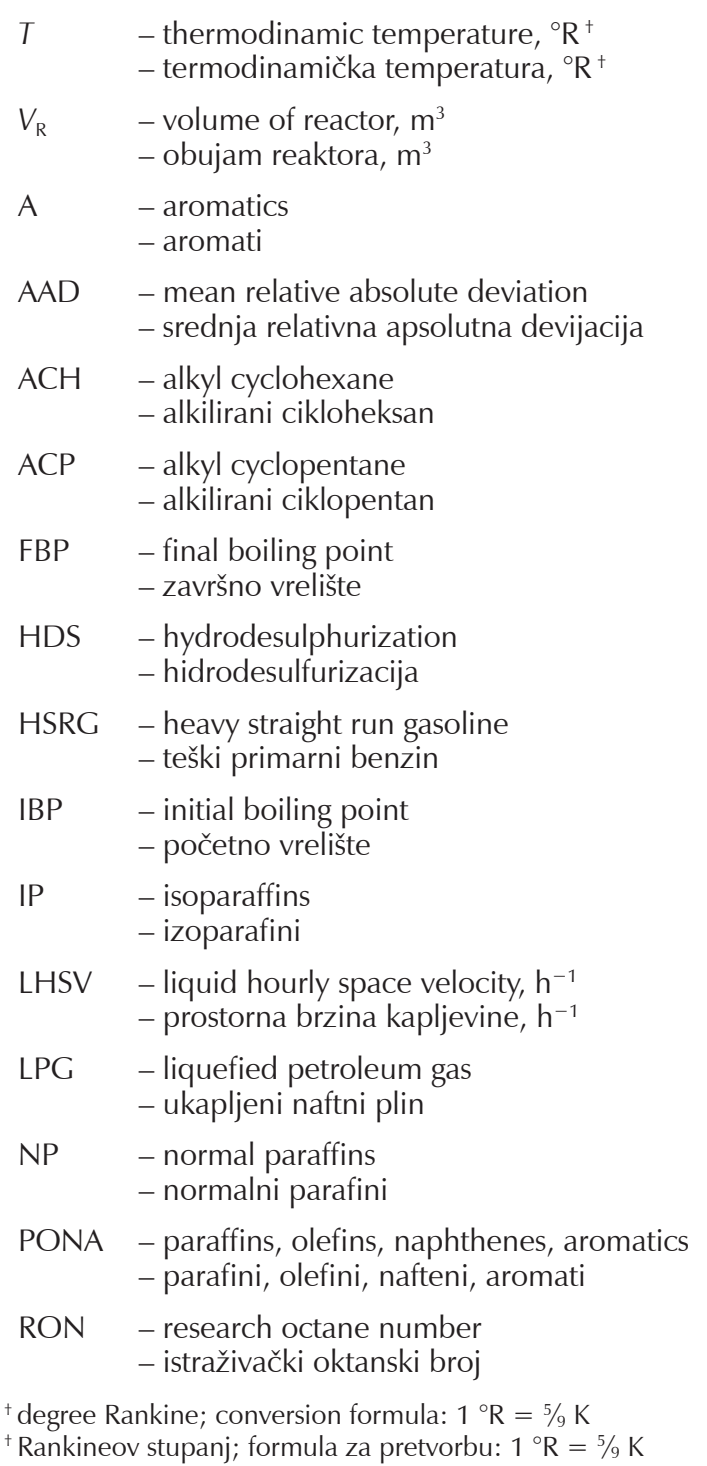

\section{References \\ Literatura}

1. A. Chang, K. Pashikanti, Y.A. Liu, RefineryEngineering, John Wiley \& Sons, 2012, http://dx.doi.org/10.1002/9783527666836

2. M. A. Fahim, T. A. Al-Sahhaf, A. Elkilani, Fundamentals of Petroleum Refining, Elsevier, 2009.

3. G. J. Antons, A. M. Aitani, Catalytic Naphtha Reforming, $2^{\text {nd }}$ Ed., Marcel Dekker Inc., 2004, http://dx.doi. org/10.1201/9780203913505.

4. R. B. Smith, Kinetic Analysis of Naphtha Reforming with Platinum Catalyst, Chem. Eng. Prog. 55 (6) (1959) 76-80.

5. U. Taskar, J. B. Riggs, Modeling and optimization of a semi-regenerative catalytic naphtha reformer, AIChE J. 43 (3) (1997) 740-753, http://dx.doi.org/10.1002/aic.690430319.

6. G. Padmavathi, K. K. Chaudhuri, Modeling and simulation of commercial catalytic naphtha reformers, Can. J. Chem. Eng. 75 (10) (1997) 930-937.

7. J. Ancheyta, E. Villafuerte, Kinetic Modeling of Naphtha Catalytic Reforming Reactions, Energy \& Fuels 14 (5) (2000) 1032 1307, http://dx.doi.org/10.1021/ef0000274.

8. M. R. Rahimpour, S. Esmaili, G. N. A. Bagheri, A kinetic and deactivation model for industrial catalytic naphtha reforming, Iran. J. Sci. Technol., Trans. B: Tech. 27 (2003) 279-290.

9. W. Hou, H. Su, J. Chu, Modeling, Simulation and Optimization of a Whole Industrial Catalytic Naphtha Reforming Process on Aspen Plus Platform, Chinese J. Chem. Eng. 14 (5) (2006) 584 591, http://dx.doi.org/10.1016/S1004-9541(06)60119-5.

10. H. M. Arani, M. Shirvani, K. Safdarian, E. Dorostkar, Lumping procedure for a kinetic model of catalytic naphtha reforming, Braz. J. Chem. Eng. 26 (2009) 723-732, http://dx.doi. org/10.1590/S0104-66322009000400011.

11. A. Fazeli, S. Fatemi, M. Mahdavian, A. Ghaee, Mathematical Modeling of an Industrial Naphtha Reformer with Three Adiabatic Reactors in Series, Iran. J. Chem. Chem. Eng. 51 (3) (2009) 97-102.

12. Z. M. Shakoor, Catalytic reforming of heavy naphtha, analysis and simulation, Diyala J. Eng. Sci. 4 (2) (2011) 86-104.

\title{
SAŽETAK \\ Razvoj kinetičkog modela poluobnavljajućeg katalitičkog reformiranja benzina u ustaljenom stanju u industrijskom mjerilu
}

R. Seif Mohaddecy* i S. Sadighi

\begin{abstract}
Zbog velike potražnje za visokooktanskim benzinom kao transportnim gorivom, katalitičko reformiranje benzina postalo je jedan od najvažnijih procesa u rafinerijama nafte. Da bi se predvidjele vrijednosti važnih izlaznih varijabli, u ovom je istraživanju modelirano katalizirano reformiranje benzina u ustaljenom stanju s nepokretnim slojem katalizatora. Te su varijable oktanski broj, iskorištenje, čistoća vodika i temperatura u svim reaktorima za reformiranje. Stoga je proučena i modelirana jedinica za poluobnavljajuće katalitičko reformiranje benzina u industrijskom mjerilu, a vrijednosti izlaznih varijabli uspoređene su sa stvarnim podacima. Rezultati su pokazali dobro slaganje stvarnih i predviđenih vrijednosti. Srednje relativno apsolutno odstupanje izlaznih temperatura reaktora, oktanskog broja, iskorištenja, čistoće vodika i temperature iznosi 0,38 \%, 0,52 \%, $0,54 \%, 0,32 \%, 4,8 \%$ i $3,2 \%$.
\end{abstract}

Catalysis and Nanotechnology Research Division,

Catalytic Reaction Engineering Department,

Research Institute of Petroleum Industry,

West Blvd. of Azadi Sports Complex, Tehran, Iran
Prispjelo 11. travnja 2013. Prihvaćeno 4. lipnja 2013. 